\title{
Comparative analysis of the TXM business infographic: the use of visual tools to aid in the design creation
} process

Análise comparativa do infográfico TXM business: o uso de ferramentas visuais para auxiliar no processo de criação em design

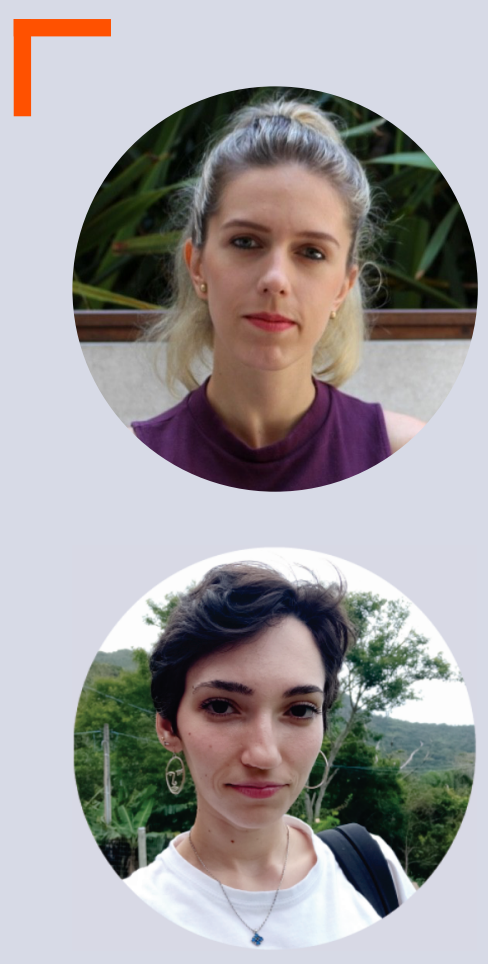

\section{Naiane Cristina Salvi}

Master of Design from the Federal University of Santa

Catarina

PhD Candidate at the Federal University of Santa

Catarina

nai.salvi@gmail.com

\section{Hecate Torres-Angenot}

Graduated in Design from Federal University of Santa

Catarina

Designer at TXM Methods

torresangenot@gmail.com 


\section{Paola Gallert Thomé Da Cruz}

Graduated in Design from Federal University of Santa Catarina

Social Media Designer

paolagallert@outlook.com

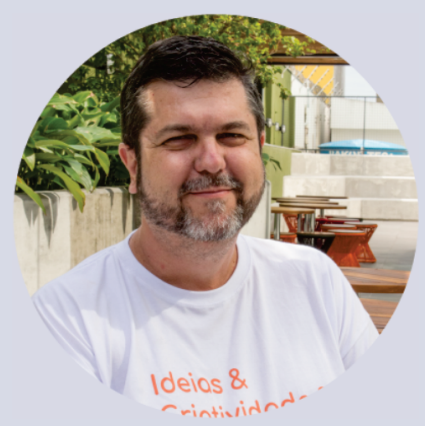

\section{Luiz Salomão Ribas Gomez}

PhD in Production Engineering from the Federal University of Santa Catarina

Senior Researcher at Federation of Industries of the State of Santa Catarina

Professor at Federal University of Santa Catarina salodesigner@gmail.com

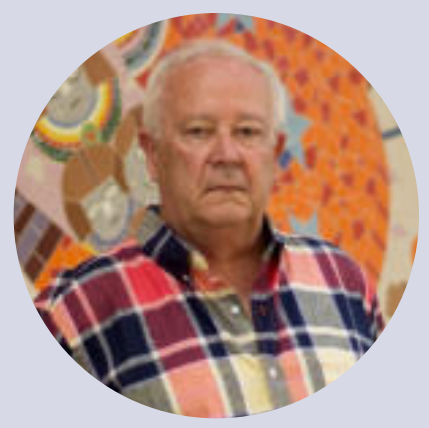

\section{Francisco Antônio Pereira Fialho}

PhD in Production Engineering, Knowledge Engineering, from Universidade Federal de Santa Catarina Titular Professor at Federal University of Santa Catarina fapfialho@gmail.com 


\section{ABSTRACT}

Infographics were born to represent information, seeking to unite text and images to make information more straightforward to understand its context. Considering everything infographics represent in this informational society, we propose, based on a study of the elements that make up infographics, to validate the infographic referring to the TXM Business Methodology developed from another methodology used for brand creation and management TXM Branding. The primary purpose of creating such an infographic is to make information accessible to visualize the complete methodological process. Thus, the objective of this article is to analyze, based on the literature, the composition of the infographic of the TXM Business methodology in its two versions, allowing us to trace a relationship between them concerning their graphic elements. Therefore, to analyze and compare the two versions of TXM Business infographics, it was necessary to understand infographics and research construction methodologies to subsequently relate these learnings to the infographic and analyze it for future validation. The results point to a balanced composition that highlights the main approaches and information of the Methodology. The final object can be improved by understanding the field ofinfographics.

\section{KEYWORDS}

Infographics; TXM Business; Visual Perception.

\section{RESUMO}

A infografia nasceu como uma forma de representar a informação, buscando unir textos e imagens a fim de tornar a informação mais simples de ser compreendida em seu contexto. Levando em conta tudo que a infografia representa nessa sociedade informacional, propomos, com base em um estudo de elementos que compõem infográficos, validar o infográfico referente a Metodologia TXM Business desenvolvida a partir de outra metodologia utilizada para criação e gestão de marcas nomeada TXM Branding. O intuito principal da criação de tal infográfico é, além de tornar a informação acessível, garantir a visualização do processo metodológico completo. Desta forma, o objetivo deste artigo é analisar com base na literatura a composição do infográfico da metodologia TXM 


\section{RESUMO}

Business em suas duas versões, permitindo traçar uma relação entre eles em relação aos seus elementos gráficos. Portanto, para analisar e comparar as duas versões de infográficos da TXM Business, foi necessário entender os conceitos sobre infografia, pesquisar metodologias de construção para posteriormente relacionar esses aprendizados com o infográfico e analisá-lo para uma futura validação. Os resultados apontam para uma composição equilibrada que evidencia as principais abordagens e informações da metodologia representada, mas que compreendendo o campo da infografia, o objeto final pode ser aprimorado.

\section{PALAVRAS-CHAVE}

Infografia; TXM Business; Percepção Visual. 


\section{INTRODUCTION}

The Information Age has established itself, changing the world, especially global communication. The search for information in an indefinite amount of data becomes tiresome. According to Wurman (2001), despite the access to information is available to everyone at all times, there is so much shuffled data that it becomes difficult to get to the information concisely, bringing the discussion of the accessibility of this information.

Thus "as content gushes through countless channels 24 hours a day, the rules of navigation change, information architects are forced to rethink what to do to make the journey more meaningful" (WURMAN, 2001, p.9). So, with such a massive amount of data, organizing it to give meaning and transform it into information becomes a constant search, making it necessary to develop new ways to facilitate the search for meaningful information.

Thus, infographics were assumed to represent information, uniting images and text to make information more accessible.

This format has been adopted by different types of publications since, by being predominantly visual, it can be read in less time than the written text, becoming more intelligible to a large portion of the population. (MENEZES and PEREIRA, 2016, p.4688 - our translation).

However, according to Rajamanickam (2005, apud CARVALHO and ARAGÃO, 2012), building the visual representation of information is not a mere translation of what can be read for what can be seen. It involves filtering information, establishing relationships, differentiating patterns, and representing them in a way that allows the reader to understand that such information builds something meaningful.

Considering everything that infographics represent in this informational society, it is proposed, based on a study of elements that make up infographics, to validate the infographic referring to the TXM Business Methodology.

This Methodology was developed from the TXM Branding methodology, proposed by Gomez (2011) for brand creation and management. TXM Business, also proposed by Gomez (2018), was tested through successful experiences in the business pre-incubator Cocreation Lab located in Florianopolis. The approach of the TXM Business 
methodology, whose focus is on the construction, validation, and solidification of businesses, is based on the combination of management methods and tools. The TXM Business is characterized as a hybrid methodology emphasizing UX (user experience), communication, entrepreneurship, and marketing. Also, it has the co-creation as a premise, ensuring the involvement and active participation of the people involved in the business context, allowing different views and ideas about its construction.

This methodological structure, divided into three essential steps, generated a first and second version of an infographic representing the entire methodological process, proposing a non-linear way of reading. The infographic creation purpose seeks to make the information accessible, to ensure the visualization of the complete process, as is suggested as a function of infographics by Teixeira (2018). The author shows that working processes visually decrease the chance of misunderstandings, as it helps in visualizing the whole. In addition, Horn (1998, apud CARVALHO and ARAGÃO, 2012, p.163) complements that an infographic is considered an autonomous communication unit because its understanding does not depend on a context. Therefore, it is understood that an infographic must convey the necessary information, making it possible to understand even for those who are not inserted in the work context.

In summary, to analyze and compare the two versions of infographics from TXM Business, it was necessary to research and understand the concepts about infographics, research construction methodologies to subsequently relate these learnings to the infographic and analyze it for future validation.

\section{METHODOLOGICAL APPROACH}

The present work focuses on analyzing the infographic of the TXM methodology based on the prerogatives of infographics highlighted in a literature review. For this study, we subdivided the research into three stages, they are:

1. Literature review on infographics and the elements that compose it in articles and books related to the topic; 2 . Literature-based description of the graphic elements that compose the infographic of the TXM Business Methodology. 3. Present the analyzed results: Conclusions about the TXM Business Infographic. 


\section{INFOGRAPHY}

Infographic is a visual language widely used in various areas of knowledge, such as science, economics, and journalism. Currently, where there is a dependence on data at all times, one of the most complex social problems is access to information, where "despite the ease of access, these data are not always, in fact, the "valuable information", ready to be consumed comfortably and effectively" (OLIVEIRA et al. 2017, p.288).

Several authors had expressed their idea on the issue that remnants of what we currently know as infographics began in human history before the terminology "Infographic" was invented. De Pablos (1999, apud CARVALHO e ARAGÃO, 2012) states that it is already possible to consider infographics as what was done in the early days of human communication, when the union between image and text was made, because, for him, infographics represent the presence of the binomial image+text, whatever the support where this informative union is presented: screen, paper, plastic, clay, parchment, papyrus or stone. However, we are not sure exactly, at least to this research extent, when and where the infographics started to be used in the manner that occurs nowadays.

Although the term "infographic" is relatively recent, its essential characteristics of synthesis and graphic representation have been observed for a long time. Man has always felt the need to combine visual and verbal forms to express and communicate. As he evolved as a social being, he was creating documents and graphic artifacts that left marks in the history of humanity, as is the case of ceramic accounting blocks (c.3300 ac.) [...] (OLIVEIRA et al. 2017, p.289 - our translation)

During the Industrial Revolution, the printing advancement and reproduction technologies, in addition to the growing interest in communication through images at the time, were pointed as determining factors for the development of infographics (MIRANDA and ANDRADE, 2017, p.382).

In the mid-1930s, Otto Neurath, Gerd Arntz, and Marie Neurath developed ISOTYPE (International System Of TYpographic Picture Education), which consisted of a standardized system of pictograms on economic, political, and social issues. These pictorial elements contributed significantly to the development of several infographics about the time.

In the late twentieth century, the beginning of the Information Age was marked by the growing commercial use of the internet and the advent of 
online newspapers. These changes provided the creation of graphic pieces with new techniques and compositions, enriching more complete definitions and developing methodologies for creating and analyzing elements belonging to an infographic (MORAES, 2010).

For Lima (2009, apud MIRANDA e ANDRADE, p. 377), an infographic is characterized as "a graphic piece that simultaneously uses verbal graphic, schematic, and pictorial language, aimed primarily at explaining some phenomenon". Moreover, other essential factors addressed in these analyses are the classification of each element that makes up the infographic. Valero Sancho (2001), for example, presents the concept of elementary graphic units: texts; numbers; icons; figurative and abstract ornaments; figurative drawings; photographs; boxes, lines, and driving points; reticules and backgrounds.

Thanks to the "possibility of using graphic interfaces, infographics bring together visual and multimedia resources available in cyberspace, besides being used in different informational environments, whether physical or digital." (PADUA et al., 2015, p.289). However, the mentioned authors summarized that this transmission of information concept with the combination of text and images could be considered insufficient in the face of technological development that has provided the interactivity of infographics from the beginning of the twenty-first century. Figure 1 presents a timeline structure containing some aspects that contributed to the evolution of infographics.

Figure 1 - Timeline of aspects that contributed to the evolution of infographics.

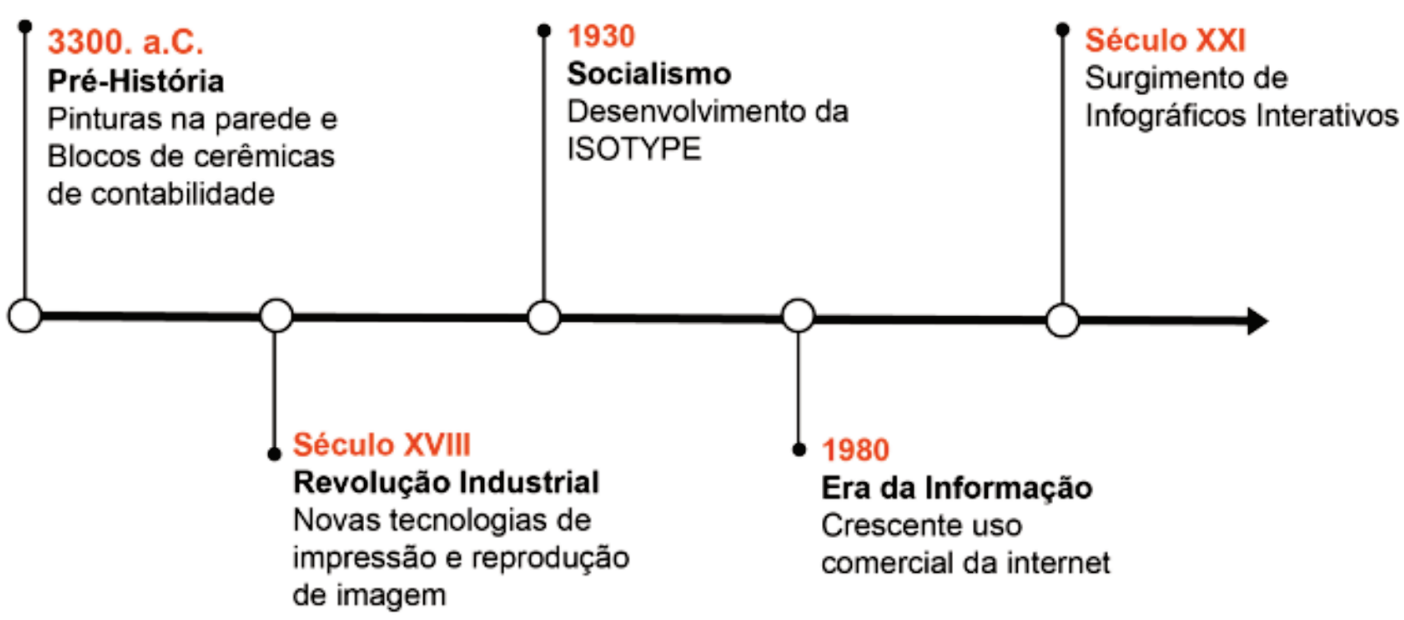

Source: Prepared by the authors (2021). 
According to Oliveira et al. (2017, p.288 - our translation), the professional of Information Design "already deals, historically, with the need and the challenge of presenting and making available all kinds of messages (simple or complex) in a meaningful and easy-to-understand way". The current amount of data offered daily makes necessary the improvement of the professional who works with Information Design and the updating of this term to adapt to what the technological world can offer. So all that is needed is the adaptation and integration to the new technologies available in the market to ensure that, among all the load of information received, the user can have his attention directed to this crucial informational tool and can perceive the infographic as a valuable source of information.

\subsection{How an infographic is built:}

\section{methodologies for building an infographic}

To infographics understanding, it is essential to consider the technical approach by analyzing its elements, organization, and colors. These attributes show the infographic construction as something beyond the simple synthesis and informational organization, but as something planned to mess with our perception, naturally directing the reader and using details sharpened by our cultural and social knowledge.

Several validated methodologies for building an infographic that helps decide its elements until its final development. Freitas et al. (2013) analyzed and compared three primary methodologies used for building infographics from Information design in a table. In Table 1, the methodologies of Redish (2000), Sless (2003), and Smiliger (2007) are cited:

Table 1 - Comparison of Information Design methodologies.

\begin{tabular}{|c|c|c|c|}
\hline Fase/Author & Redish (2000) & Sless (2003) & Smiliger (2007) \\
\hline 1 & $\begin{array}{l}\text { Information Plan } \\
\text { 1. What are your goals? } \\
\text { 2. Who will use it? } \\
\text { 3. How will they use it? } \\
\text { 4. Where will they use it? } \\
\text { 5. What information do they } \\
\text { need? }\end{array}$ & $\begin{array}{l}\text { Scope or Delineation } \\
\text { Identify the socio-economic } \\
\text { and political context, legal, } \\
\text { regulatory, and technical } \\
\text { constraints to be taken into } \\
\text { consideration when } \\
\text { designing, as well as the } \\
\text { definition of performance } \\
\text { requirements for the } \\
\text { information. }\end{array}$ & $\begin{array}{l}\text { Understanding the topic } \\
\text { and its value to the user } \\
\text { 1. Unlocking the information } \\
\text { thlat needs to be designed. } 2 \text {. } \\
\text { Becoming familiar with the } \\
\text { meaning of the information } \\
\text { and the environment where it } \\
\text { is intended to be } \\
\text { presented/disseminated } \\
\text { al ows for a better } \\
\text { understanding of the } \\
\text { purpose of the information. }\end{array}$ \\
\hline
\end{tabular}




\begin{tabular}{|c|c|c|c|c|}
\hline Fase/Author & \multicolumn{2}{|c|}{ Redish (2000) } & Sless (2003) & Smiliger (2007) \\
\hline 2 & $\begin{array}{l}\text { Project Plan } \\
\text { 1. Schedule } \\
\text { 2. Budget } \\
\text { 3. Production team } \\
\text { 4. Style standardizatid } \\
\text { 5. Usability exercise } \\
\text { 6. Other issues }\end{array}$ & & $\begin{array}{l}\text { Diagnostics and Analysis } \\
\text { Diagnose and analyze errors } \\
\text { to find out how the existing } \\
\text { information is performing in } \\
\text { relation to the performance } \\
\text { requirements agreed upon } \\
\text { and defined in the scoping } \\
\text { phase. }\end{array}$ & $\begin{array}{l}\text { Understanding Users } \\
\text { 1. Define the user(s), through } \\
\text { appropriate methods, such as } \\
\text { observation, interviews and } \\
\text { development of personas. } \\
\text { (controlled in the lab and in } \\
\text { real life) } \\
\text { 2. Develop scenarios where } \\
\text { "personas" perform the } \\
\text { activities/actions that the } \\
\text { information should facilitate } \\
\text { 3. Be aware that activities } \\
\text { never exist in isolation, there } \\
\text { is always a before and after, } \\
\text { one must consider the "chain } \\
\text { of activities". }\end{array}$ \\
\hline 3 & $\begin{array}{l}\text { Content Selection/P } \\
\text { Organization } \\
\text { 1. Information gather } \\
\text { 2. Content selection } \\
\text { 3. Material organizati } \\
\text { 4. Preparation of stru } \\
\text { 5. Iayout plan of each } \\
\text { screen } \\
\text { 6. Test organization o } \\
\text { material with users } \\
\text { 7. Review based on us } \\
\text { test }\end{array}$ & $\begin{array}{l}\text { age } \\
\text { fng } \\
\text { pability } \\
\text { page or }\end{array}$ & $\begin{array}{l}\text { Design } \\
\text { Using appropriate graphics, } \\
\text { typography, layout, colors, } \\
\text { language and structure to } \\
\text { present the information at a } \\
\text { higher level than the analysis } \\
\text { phase. }\end{array}$ & $\begin{array}{l}\text { Proposal or Strategy } \\
\text { 1. The infodesigner is ready } \\
\text { to make his proposal which } \\
\text { outlines the result to be } \\
\text { achieved, where technical } \\
\text { and legal standards should } \\
\text { be stressed, and how much } \\
\text { time and money will be } \\
\text { invested. 2. Define objectives }\end{array}$ \\
\hline 4 & $\begin{array}{l}\text { Outline and Test } \\
\text { 1. Sketch Generation } \\
\text { 2. Aesthetic productio } \\
\text { 3. Working with text a } \\
\text { image } \\
\text { 4. Testing of sketches } \\
\text { users } \\
\text { 5. Review and suppler } \\
\text { 6. Review the effective } \\
\text { the information } \\
\text { 7. Improve consisten } \\
\text { usability } \\
\text { 8. Review } \\
\text { 9. New usability test } \\
\text { users (repeat until do } \\
\text { is finalized and workin } \\
\text { users) }\end{array}$ & $\begin{array}{l}\text { on } \\
\text { with } \\
\text { anent } \\
\text { eness of } \\
\text { gy and } \\
\text { with } \\
\text { pument }\end{array}$ & $\begin{array}{l}\text { Testing } \\
\text { Test, analyze, and diagnose } \\
\text { how the new information is } \\
\text { performing against the } \\
\text { performance requirements } \\
\text { agreed upon and defined in } \\
\text { the analysis and scoping } \\
\text { phase. }\end{array}$ & $\begin{array}{l}\text { Project } \\
\text { 1. Composition of } \\
\text { information using verbal, } \\
\text { pictorial, acoustic, haptics } \\
\text { and/or olfactory elements, } \\
\text { which are shaped, and } \\
\text { structured according to the } \\
\text { principles of cognitive and } \\
\text { perceptual psychology. } \\
\text { 2. Definition, planning and } \\
\text { shaping of the message } \\
\text { content and the } \\
\text { environments in which it will } \\
\text { be presented. }\end{array}$ \\
\hline 5 & $\begin{array}{l}\text { Final Production } \\
\text { 1. New Revision } \\
\text { 2. Know what technol } \\
\text { needed before releas } \\
\text { 3. Production and rele }\end{array}$ & gase is & $\begin{array}{l}\text { Redefining } \\
\text { Using appropriate graphics, } \\
\text { typography, layout, colors, } \\
\text { language and structure to } \\
\text { remove errors in the } \\
\text { information so that it exists } \\
\text { at a higher level than the } \\
\text { analysis phase. }\end{array}$ & $\begin{array}{l}\text { Evaluation } \\
\text { 1. Were the objectives of the } \\
\text { tasks related to knowledge } \\
\text { transfer achieved? Did they } \\
\text { yield the desired effect? } \\
\text { 2. Use insights from cognitive } \\
\text { psychology to conduct user } \\
\text { interviews, apply evaluation } \\
\text { methods, and know how to } \\
\text { interpret the results. } \\
\text { 3. Concept testing, focus } \\
\text { group, usability testing, } \\
\text { participatory design, and } \\
\text { design testing. }\end{array}$ \\
\hline
\end{tabular}




\begin{tabular}{|c|c|c|c|c|}
\hline Fase/Author & Redish (200 & & Sless (2003) & Smiliger (2007) \\
\hline 6 & $\begin{array}{l}\text { Continuous Process } \\
\text { 1. Gathering feedback } \\
\text { 2. Using feedback for } \\
\text { 3. Keeping up to date }\end{array}$ & revision & $\begin{array}{l}\text { Implementation } \\
\text { Ensure that final designs are } \\
\text { faithfully implemented in } \\
\text { production, with the approval } \\
\text { of all stakeholders. }\end{array}$ & $\begin{array}{l}\text { Information Refinement } \\
\text { and Implementation } \\
\text { 1. Based on insights gained } \\
\text { from testing: optimize design } \\
\text { content, consider } \\
\text { alternatives, or identify } \\
\text { obstacles that can be } \\
\text { overcome with a change in } \\
\text { direction. } \\
\text { 2. Subsequently assist in the } \\
\text { implementation of the } \\
\text { design(s) and, if necessary, } \\
\text { make adjustments and } \\
\text { modifications in response to } \\
\text { changing requirements. }\end{array}$ \\
\hline 7 & - & & $\begin{array}{l}\text { Monitoring } \\
\text { Measurement to ensure that } \\
\text { the performance of the } \\
\text { information is maintained } \\
\text { throughout its use. }\end{array}$ & - \\
\hline
\end{tabular}

Source: Adapted from Freitas et al. (2005).

The three methodologies shown in Chart 1 are very similar to each other. Thus, it is possible to analyze that the authors agree with many of the points mentioned. A differential pointed out in these methodologies is the implementation of collaborative design, valuing the participation of their customers in various stages of the process, besides the monitoring after the final delivery.

Another exciting point analyzed is the proposal of a cyclical methodology, i.e., non-linear, allowing the return to previous stages to enrich the quality of the final result. These two characteristics are identified in the infographic representation and the TXM Business methodology, which will be analyzed throughout this article.

Carvalho and Aragão (2012) carried out an analysis of methodologies used by designers in the market. Considering all the stages pointed out, a new methodology was developed that is simplified into only three main stages: Conception, Execution, and Finishing. These steps proposed by Carvalho and Aragão (2012) appear, implicitly, in the methodologies of the three authors of Table 1, despite being more extensive and complete. Table 2 presents a relationship between the methodologies for creating infographics with the graphic design methodology proposed by Carvalho and Aragão (2012). In addition to the similarities cited, these three methodologies are also very similar to the traditional graphic design methodologies used. 
Table 1 - Comparison of Information Design methodologies.

\begin{tabular}{|c|c|c|c|c|}
\hline & $\begin{array}{l}\text { Carvalho e Aragão } \\
\text { (2012) }\end{array}$ & Redish (2000) & Sless (2003) & Smiliger (2007) \\
\hline 1 & Design & $\begin{array}{l}\text { Information Plan,Project } \\
\text { Plan, Content } \\
\text { Selection/Page } \\
\text { Organization }\end{array}$ & $\begin{array}{l}\text { Scope or Delimitation, } \\
\text { Diagnosis and Analysis }\end{array}$ & $\begin{array}{l}\text { Understanding the topic } \\
\text { and its value to the user, } \\
\text { Understanding the } \\
\text { users, Proposal or } \\
\text { Strategy. }\end{array}$ \\
\hline 2 & Execution & Drafting and Testing & Design, Testing & Design, Evaluation \\
\hline 3 & Finishing & $\begin{array}{l}\text { Final Production, } \\
\text { Continuous Process }\end{array}$ & $\begin{array}{l}\text { Redefinition, } \\
\text { Implementation, } \\
\text { Monitoring }\end{array}$ & $\begin{array}{l}\text { Information Refinement } \\
\text { and Implementation }\end{array}$ \\
\hline
\end{tabular}

Source: Prepared by the authors (2020).

One can observe that all four methodologies in Table 2 are placed in parallel correlate because they present a similar direction and show how the complexity of developing an infographic equals the complexity of any other project involving graphic design methodologies.

For an infographic to convey information clearly and concisely, all elements involved in visual perception must be well planned and precise. That is why it is necessary to rely on existing methodologies and thus communicate in the desired way with the viewer.

\subsection{Visual perception: influence of the}

\section{elements and colors}

According to Modesto Farina (2011), for the human being, anything that stimulates one of his five senses unexpectedly calls his attention, causing stimuli in our brain. When it comes to visual perception applied to graphic arts, the colors and shapes representing objects govern our perception of the graphic pieces. Furthermore, using "their characteristics, such as size, proximity, lighting, color" (FARINA, 2011, p.29 - our translation) generates stimuli and conveys messages.

The influence of colors on the human brain occurs both to organize information and the interpretation of the visual stimulus received. As Menezes and Pereira (2017, p.322) point out, "on the one hand, [colors] act in the mechanisms of perception to differentiate, highlight and unify other plastic elements. On the other, through mental associations, colors can represent concrete objects or abstract ideas, functioning as signs." 
However, from the perspective of graphic language,

Although the term "infographic" is relatively recent, its essential characteristics of synthesis and graphic representation have been observed for a long time. Man has always felt the need to combine visual and verbal forms to express and communicate. As he evolved as a social being, he was creating documents and graphic artifacts that left marks in the history of humanity, as is the case of ceramic accounting blocks (c.3300 ac.) [...] (OLIVEIRA et al. 2017, p.289 - our translation)

Such difficulties encountered in the employment of color symbology are given by its cultural and contextual influence, making the color a complement of interchangeable semantics in delivering information. Despite being at the mercy of different symbologies, when we talk about infographics, its role of colors goes beyond representation, because according to Menezes and Pereira (2016), its inclusion also has a role of attraction,

Besides these elements' self-relation and their importance for the information understanding, the color becomes essential for the infographic composition due to its perceptual (of visual attraction) and semantic (of association and meaning) characteristics (MENEZES; PEREIRA, 2016, p.2 - our translation).

The same authors cite that "Its use as an information resource initially concerns its potential to act as an element of visual attraction, being able to facilitate the identification of the message." (MENEZES; PEREIRA, 2016, p. 4). The color's function to attract and keep the reader's attention also facilitates their understanding through focus. In addition, the authors compliment by stating that, when combined with other elements, color can give evidence to the main points of the message to be transmitted, classifying the information in a hierarchical and representative way (MENEZES; PEREIRA, 2016).

\section{GRAPHIC ELEMENTS OF THE TXM BUSINESS INFOGRAPHIC}

This section presents the TXM Business methodology and the graphic elements organized into its infographic. Two versions of the Methodology's infographic were developed to write this work, prepared by Ph.D. Priscila Zavadil Pereira. The two versions are presented and analyzed 
by the authors.

\subsection{TXM BUSINESS METODOLOGY}

Given the frequent emergence of new technologies, new consumption needs also arise and possibilities of insertion of new businesses. As a result of their needs, these businesses have proven to be increasingly creative and scalable, offering new ideas and ways of dealing with problems, giving rise to new economies.

Technological innovation causes changes in work relations as the massification of the internet increases connectivity and breaks down physical and geographical barriers. Consequently, new ways of working and doing business are opening up, increasingly networked (FIRJAN, 2020, p.9 - our translation).

With the Creative Economy advent, an industry that "configure a new field of study still in the solidification phase" (COSTA e SOUZA-SANTOS, 2011, p.2 - our translation), the so-called Startups began to emerge. According to Cockayne (2019), startups are new companies that are modern, innovative, and consolidate new ways of working with an essentially technological base.

With these new businesses emerging, new initiatives also emerged to support them. The term "pre-incubation" is defined as a process that "acts as a mentorship for companies to enter the market more prepared to face it and having a better understanding of themselves and their market of operation" (SALVI et al., 2019, p.2 - our translation). In this sense, the preincubator Cocreation Lab emerged in Florianópolis in 2016, where the TXM methodology was born, took shape, and was validated.

The Cocreation Lab offers a pre-incubation process. Among other things, it questions the purpose of the companies' existence, allows analysis on the intended structure of the business, helping to strengthen and structure it. In addition, it provides an understanding of the operating segment, competitors, target audience, and the formulation of strategies for managing a brand. All this information is planned and validated directly in the market. (SALVI et al., 2019, p.2)

To strengthen the process and consolidate it in a way that contemplates all the aspects of structuring a business, Cocreation Lab began to apply the TXM Business Methodology. This Methodology was based on the TXM Branding Methodology, sharing its structure and part of its tools but expanding the initial focus from brand creation and 
management to the creation and structuring of companies.

The TXM Business Methodology, whose visual representation is presented in topic 4.2 (figure 02), is divided into three significant steps Think ( $\mathrm{T})$, Experience $(\mathrm{X})$, and Manage $(\mathrm{M})$. The Think stage refers to thinking about the brand. There is the preparation in market research, search for the creative DNA, purpose, and positioning of the brand to find its differential and understand why it is needed in the market. The second stage, the Experience stage, refers to experiencing the business, transforming the results of Stage T into application strategies. It is possible to consolidate the business concepts visually and experientially and put them into practice. It also helps to understand the business's problem, the market viability for this solution, and how the MVP (Minimum Viable Product) would be. In the last stage, called the Manage stage, the company's management planning is done, including the necessary capital and legal issues that must be addressed to enter the market.

\subsection{Infographic TXM: first version}

Like the Methodology itself, the first version of the TXM Business infographic had a particular influence from the TXM Branding methodology, considering that it presents the same format of steps and some sub-steps. However, this time focused on the business context and carrying a non-linear meaning.

When this first version of the infographic was created, no particular infographic creation methodology of those cited above was used, but rather the principles that they carry (represented in Table 2). Its purpose was to function more to organize information, create more for visualization of a methodology in formation, see the project as a whole in a visual way, and facilitate the understanding of those who would apply the Methodology.

The three stages of the TXM Business methodology were previously represented through the infographic shown in Figure 2. Professor and designer Priscila Zavadil Pereira contributed to the elaboration of the infographic. When consulted about the process, she informed that the hexagons representing each sub-stage were chosen to show that they are modular steps, i.e., non-linear (PEREIRA, 2020) 
Figure 2: First version of the TXM Business Infographic

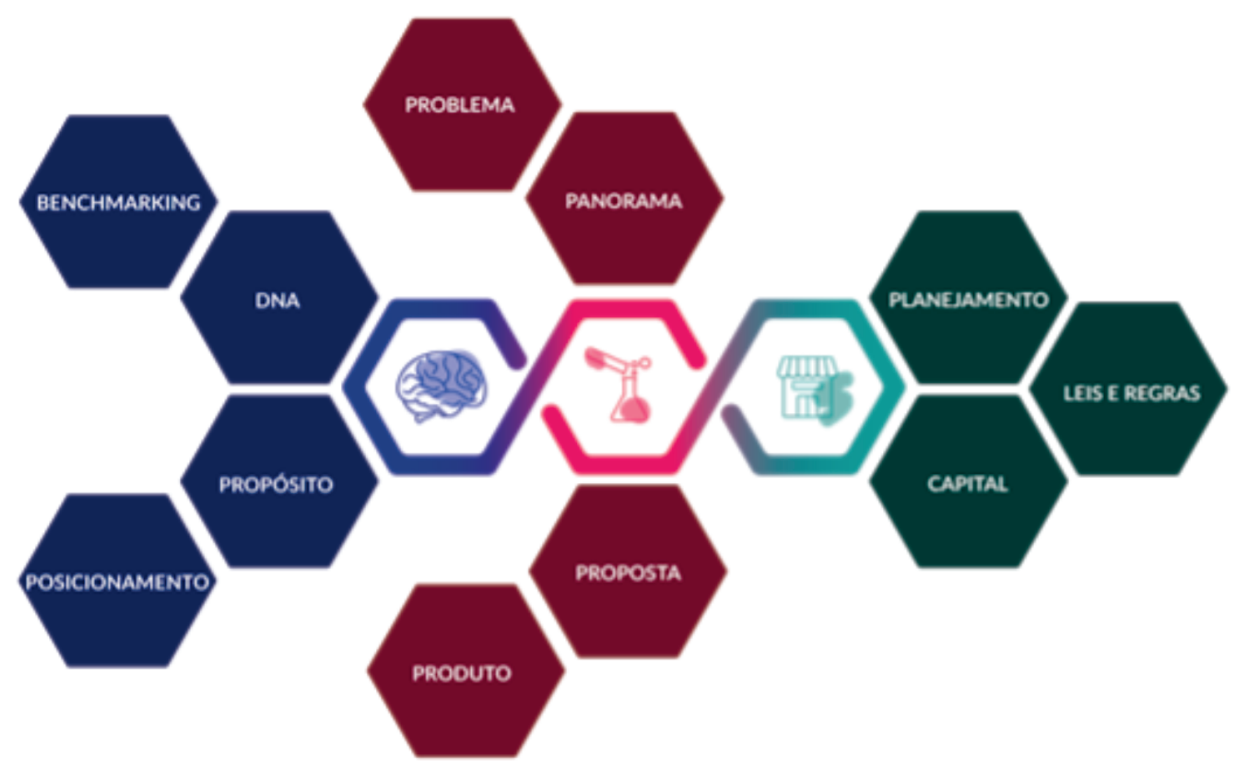

Source: https://txm.business

Despite this justification, separating each hexagon by colors and their position makes it possible to perceive a particular hierarchy when following the reading. The graphic stain indicates the direction from left to right, hindering the proposed method's non-linear application.

The colors of each stage have three low-value hues (brightness): blue, pink, and green. The sobriety caused by low saturation causes a solid and unappealing impression, not harmonizing with the hues of the three primary colors presented through a gradient.

The other elements, such as typography and icons, are presented in the following topic for not having suffered changes.

\subsection{TXM infographic: current version}

The redesign of the new infographic included several changes for a better understanding of the tool to convey confidence and solidity to an audience of public institutions, investors; and, at the same time, an audience of new entrepreneurs and startups. According to Zavadil Pereira (2020), these changes were necessary because reading TXM Business as it points out, it was necessary to make the language friendly, bringing closer the people involved with the development of business. 
Figure 2: The current version of the TXM Business infographic

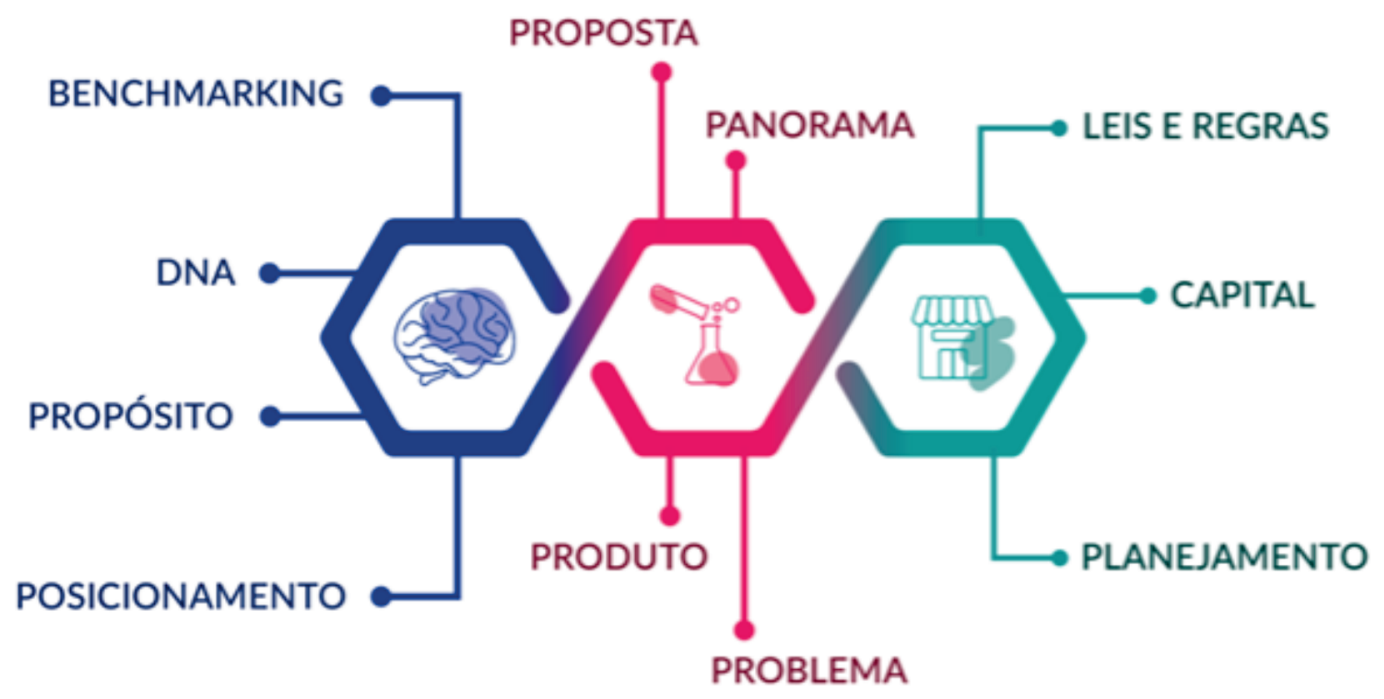

Source: https://txm.business

The infographic TXM business can be considered an interactive infographic since handled on the website https://txm.business/. It allows the user to click and manipulate each topic to deepen the information needed for the practical application of the methodological tool. According to Padua et al. (2020) definitions cited above, this element can be considered schematic, and it shows how technology has provided changes for the construction and reading of an infographic.

Since its first version, this infographic has not changed its verbal language and continues to present the Methodology with the exact subtopics. However, its optical unit has changed by excluding the hexagons of these exact subtopics. The connection and appearance of non-linearity were emphasized, increasing the user's freedom to build their hierarchy without losing the concise understanding of the step each part concern.

It is interesting to note how both keep their primary information in central prominence. The icons representing the TXM steps, respectively, remain surrounded by a shape that recalls DNA and the infinity symbol. These signs associations reinforce the importance of the decision processes of each business stage, like its DNA and all the other information explored in the Methodology.

It is worth mentioning that, in the current infographic, despite the information not being in the order of importance, the Western reading 
form conditions a linear reading from left to right, in a more subtle way than in the previous infographic, first between the main topics (TXM steps), provoking the reasoning to start with the Think Step and end with the Manage Step. The same occurs in its subtopics, where we instinctively read from left to right and top to bottom, one step at a time. Although this happens unconsciously, it is not clear whether this reading is correct, since visually, there does not seem to be an order of beginning and end.

To improve the reading and perception of an infographic, it is essential that the reader also know the image's context. Likewise, the flow or order of reading occurs, respecting specific language patterns. For the TXM Business infographic, the reading became apparent during the application of the Methodology and deepened through interactivity on the platform http://txm.business/.

\subsection{Typography}

Both infographics under comparison in this article were developed with the Lato typeface. The sans serif typeface, developed by Łukasz Dziedzic, is open-source and has a family that supports over 100 languages based on Latin, over 50 languages based on Cyrillic, and phonetics in Greek and IPA (International Phonetic Alphabet). Lato's variety can be advantageous and facilitating if the infographic needs to be translated in the future.

Comparing the two versions of the infographic, one notices that, despite having typefaces from the same family, the perception and readability of each one are different. The contrast formed between the dark colors of the hexagons and the white color of the typeface, which appears with little weight in the stroke, can make legibility difficult. In the first version of the infographic (figure 2), the bold style was used with a weight of $19.5 p t$.

In the current version of the infographic (Figure 3), the typography was changed to Lato Semibold with 26 pt. Moreover, excluding the hexagons, the texts are no longer presented on a background color, which provided the opposite filling of the same colors of their previous hexagons. These changes were positive since they enabled the improvement in the readability and legibility of the infographic. 


\subsection{Color}

The colors chosen to represent the current infographic are inspired by TXM Business' institutional colors, showing the cohesion and association throughout the Site platform. Each stage (Think, Experience, and Manage) is represented by a gradient color, showing the transition and correlation that each stage has between them. Each sub-theme has a solid color with high contrast with the background and the inserted text. Figure 4 shows the colors of TXM Business.

Figure 4: Color chart representing each step of the TXM Business methodology, blue, pink, and green.

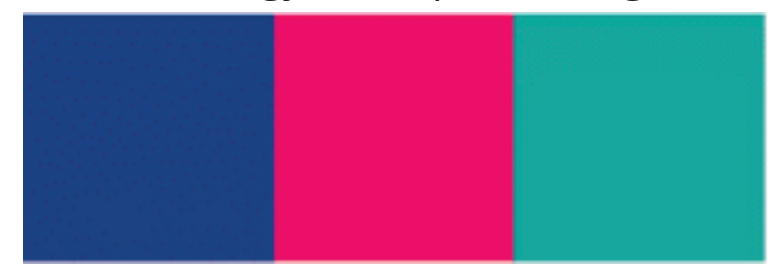

Source: https://txm.business

According to the Visual Identity of TXM Business creator, Zavadil Pereira (2020), the main goal of the color palette was to convey a friendly character to the brand, which contained the characteristic of being a facilitator into the business world since it belonged to the pre-incubator of startups Cocreation Lab. This characteristic arose from the need to communicate its connection with innovation and the world of entrepreneurship through the brand. Since the "serious" shapes already gave it a character of trust and solidity, the colors needed to help the brand communicate with its audiences (Foundations, Government, entrepreneurs, and investors).

The three solid colors can be classified as an analogous split harmony since it is formed by analogous colors located side by side on the chromatic disk. An excellent contrast is also perceived in color arranged order on the disk, where the pink is positioned in the middle of the blue and green, emphasizing each other chromatic hue.

Furthermore, the mixture of two cool colors (shades of blue and green) with the warm color (shade of pink) increases the contrast between them. Together with the saturation level of pink, a little higher than the others, manages to complement them in this sense as well, forming a balanced palette in the relationship of colors among themselves, but visually striking 
to be interesting.

In this sense, the colors in this infographic have two main functions, which, according to Menezes and Pereira (2016), in their conclusions about Tufte (2011), labeling function (distinguish the elements belonging to each stage, giving them a particular identity) and decorative function (used to attract the reader's attention).

\subsection{Icons}

The three icons, presented in the center of the two versions of the infographic, represent the three stages of the TXM Business methodology. All icons have an outline style visual pattern with the same thickness (1.5pt). The abstract filling graphic element with the appearance of a stain was chosen, according to Zavadil Pereira (2020), to provide an air of originality in icons that appear to be expected. These graphic elements in the outline have slight hue variance and did not change in the new version of the infographic.

As previously written, each icon represents a stage of the Methodology (Think, Experience, and Manage). However, this information is found implicitly since it is an interactive infographic. The infographic interaction presents the element's definition and application and can be accessed by clicking on it.

Symbolized by a brain (figure 5), the first stage (Think) represents the moment of conceptualization of the business understudy. In this stage, the Business DNA is defined, the benchmarking, the purpose, and the positioning, that is, the business's identity. The graphic representation is characterized as a stage of research, reflection, and conceptualization.

Figure 5: Icon of the Think stage

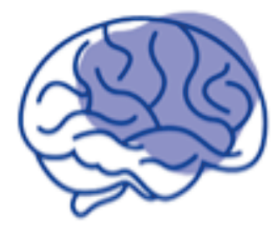

THINK

Source: https://txm.business/think

The icon that represents the Experience stage (Figure 6) symbolizes a chemical reaction through three graphic elements: an Erlenmeyer flask, a test tube, and bubbles. The goal of representing this stage as a scientific 
study refers to the moment of testing since tools are applied to improve and obtain the final business prototype. The Experience stage is the moment to define the Business Landscape (where, how, and with whom we want to be), the Problem we want to solve, the Value Proposition that will be offered (the main benefit that will be delivered to customers) and the final Product of the business.

Figure 6: Icon for the Experience step.

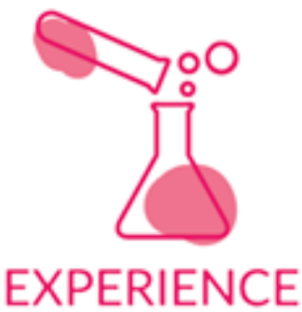

Source: https://txm.business/experience

The icon representing the Manage stage (Figure 7) represents a storefront, referring to the business in activity. This stage is the moment of concern in financial management and the application of business strategies. According to the TXM Business platform's website, this stage includes pricing, business strategies, marketing, sales, human resources, public and private funding, financing, and cash flow. Also, refer to the laws that determine the companies' creation and maintenance, such as registration and taxes.

Figure 7: Manage stage icon.

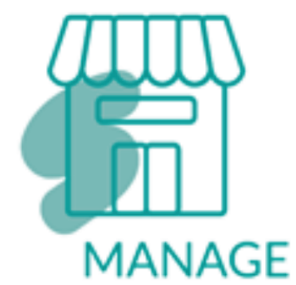

Source: https://txm.business/manage

\section{FINAL CONSIDERATIONS}

The previous literature analysis contributed to the conceptual understanding of an infographic. It allowed for in-depth analysis, comparison, and validation of the visual perception of the two versions of the TXM Business infographic. Using a non-specific methodology for 
developing an infographic may have impaired the final result of the analyzed infographics, which justifies the need for changes in the last version. The infographic construction methodologies mentioned in this article can help visualize future improvements, especially in the testing and refinement stages.

Regarding visual perception analysis, the current version of the infographic TXM Business proposes to translate the Methodology steps adequately. Its contrasting and balanced colors draw attention due to the visual stimulus of analogous colors in a different order from the one shown in the chromatic disk. They carry the concept that aims at non-linearity, where no information within the steps and between them is highlighted compared to the others, showing that they complement each other. That feature connected to different levels of saturation and brightness trigging the contrast sensation, making the infographic attractive at first sight.

Another factor that causes attraction is the use of hexagons that, despite representing well the issue of fitting together in the first version, in the second version, this meaning is lost, but still maintaining the feeling of connection between the steps. It is also believed that this form maintains an implicit semiotic issue, perceived when reading the steps linearly, from left to right starting with the Think step, giving the feeling of starting from a point, expanding, and focusing again to start a new step (Figure 8).

Figure 8: Explanation of theory for the use of the hexagon

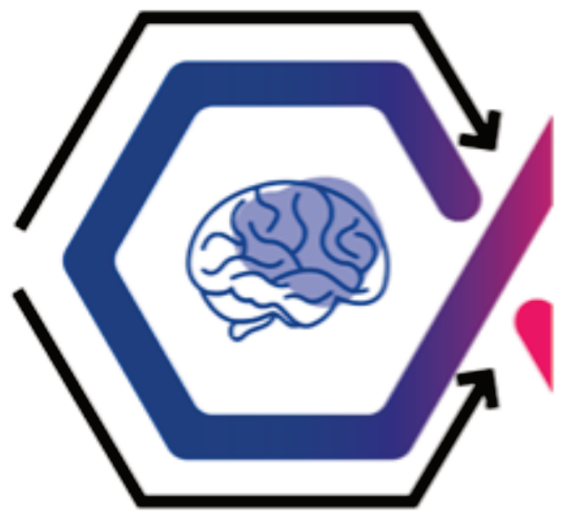

Source: https://txm.business/manage

Furthermore, the icons also refer to what is proposed by each step, easy understanding and assimilation of images with their signs and the step they represent.

Considering these points, it is possible to conclude that the analyzed infographic still has some weaknesses in the transmission of information. 
Although it is constituted from a visual logic, it can be improved to highlight the main characteristics of the Methodology that it proposes to communicate. The following steps in this work can point out the characteristics that need to be adjusted and their directions.

However, infographics prove to be an easy tool for the quick transmission of information. When structured from solid graphic elements, they play an essential role in disseminating information. Therefore, this work contributes to expanding the application of infographics to the field of entrepreneurship, strengthening design and its importance in the transmission of knowledge.

\section{REFERENCES}

CARVALHO, Juliana; ARAGÃO, Isabella. Infografia: conceito e prática. Revista Infodesign: Revista Brasileira de Design da Informação, São Paulo, v. 3, n. 9, p. 160-177, dez. 2012. Disponível em:

https://www.infodesign.org.br/infodesign/article/view/136. Acesso em: 21 abr. 2020.

COSTA, Armando dalla; SOUZA-SANTOS, Elson Rodrigo de. Economia criativa: novas oportunidades baseadas no capital intelectual. Revista Economia \& Tecnologia, Paraná, v. 25, n. 7, p. 179-186, abr. 2011. Disponível e $\mathrm{m}$

http://www.economiaetecnologia.ufpr.br/revista/25\%20Capa/Armando\% 20Dalla\%20Costa\%20-\%20EIson\%20Rodrigo\%20Souza-Santos.pdf. Acesso em: 23 mar. 2020.

COCKAYNE, Daniel. What is a startup firm? A methodological and epistemological investigation into research objects in economic geography. Geoforum, v. 107, p. 77-87, 2019.

COUTINHO, Solange Galvão; MIRANDA, Eva Rolim. Explorando conceitos: pesquisa bibliográfica e elaboração de infográfico sobre definições do campo de design da informação. Pesquisa bibliográfica e elaboração de infográfico sobre definições do campo de Design da Informação. 2017. Disponível em:

https://www.infodesign.org.br/infodesign/article/view/562. Acesso em: 16 mar. 2020.

DE MIRANDA, Fabiano; ANDRADE, Rafael de Castro. Pensar Infográfico: uma proposta de ensino introdutório de infografia sob a perspectiva da linguagem gráfica. Revista Brasileira de Design da Informação. São Paulo, v. 14, n. 3, 2017, p. 374 - 396. Acesso em: 5 junho 2020. 
FARINA, Modesto; PEREZ, Clotilde; BASTOS, Dorinho. Psicodinâmica das cores em comunicação. 6. ed. São Paulo: Editora Edgard Blucher Ltda., 2011.278 p. Edição Kindle.

FIRJAN. Mapeamento da Indústria Criativa no Brasil. 2019. Disponível em:

https://www.firjan.com.br/EconomiaCriativa/downloads/Mapeamentoln dustriaCriativa.pdf. Acesso em: 23 abr. 2020.

FONTS, Lato. The Fonts. 2012. Disponível em: http://www.latofonts.com/lato-free-fonts/. Acesso em: 13 jun. 2020.

FREITAS, Ranielder Fábio de; COUTINHO, Solange Galvão; WAECHTER, Hans da Nóbrega. Análise de Metodologias em Design: a informação tratada por diferentes olhares. Revista Estudos em Design: Design Articles, Rio de Janeiro, v. 21, n. 1, p. 1-15, abr. 2013. Disponível em:

https://estudosemdesign.emnuvens.com.br/design/article/view/111. Acesso em: 21 abr. 2020.

GOMEZ, Luiz Salomão Ribas; PEREIRA, Priscila Zavadil; SALVI, Naiane Cristina. COCREATION LAB: TRANSFORMANDO IDEIAS EM NEGÓCIOS A PARTIR DA METODOLOGIA TXM BUSINESS. In: Da teoria à ação: iniciativas empreendedoras da Universidade Federal de Santa Catarina. Organização Andressa Sasaki Vasques Pacheco et al. Editora CRV, Curitiba, 2020.

HENKEL, Evelyn; PADOVANI, Stephania. Estudo exploratório sobre satisfação e preferências dos usuários: mecanismos de interação em infografia para smartphones. InfoDesign-Revista Brasileira de Design da Informação, v. 18, n. 1, 2021.

MENEZES, Hanna França; PEREIRA, Carla Patrícia de Araújo. Funções da cor na infografia: uma proposta de categorização aplicada à análise de infográficos jornalísticos| Functions of color in infographic: a categorization proposal applied to the analysis journalistic infographics. InfoDesign-Revista Brasileira de Design da Informação, v. 14, n. 3, p. 321339, 2017.

MENEZES, Hanna França; PEREIRA, Carla Patrícia de Araújo. O uso da cor como informação: um estudo de caso dos infográficos da revista galileu. In: CONGRESSO BRASILEIRO EM PESQUISA E DESENVOLVIMENTO EM DESIGN, 12., 2016, Belo Horizonte. Proceedings [...] . Belo Horizonte: Blucher Design Proceedings, 2016. p. 4686-4697. Disponível em: https://www.proceedings.blucher.com.br/article-details/o-uso-da-corcomo-informao-um-estudo-de-caso-dos-infogrficos-da-revista-galileu24639. Acesso em: 15 maio 2020.

MORAES, A. 1998. Infografia - O design da notícia. Dissertação de 
Mestrado em Design. PUC-RJ, Departamento de Artes. Rio de Janeiro.

OLIVEIRA, Ikaro Santhiago Camara Silva; SOUZA, Angélica Porto Cavalcanti de;

PADUA, Mariana Cantisani; DIAS, Guilherme Ataíde; LIMA, Thiago Lucas Castor. Dados, formas, cores e informação: um estudo sobre construção e análise na infografia. Liinc em Revista, Rio de Janeiro P, v. 11, n. 1, p. 287-309, maio 2015. Disponível em: http://dx.doi.org/10.18225/liinc.v11i1.787. Acesso em: 30 maio 2020.

PEREIRA, Priscila Zavadil. Identidade TXM Business. [Entrevista] Mensagem recebida por:<gallert.paola@gmail.com>.em:07 jun. 2020.

SALVI, Naiane Cristina et al. PROCESSO DE PRÉ-INCUBAÇÃO COMO FOMENTO À INOVAÇÃO: O PROGRAMA COCREATION LAB. In: Anais do Congresso Internacional de Conhecimento e Inovação-ciki. 2019.

TEIXEIRA, Júlio Monteiro. Gestão visual de projetos: utilizando a informação para inovar. Rio de Janeiro: Editora Alta Books, 2018.208 p.

TXM Business. Metodologia de idealização para Pré-incubação de negócios. TXM Business, 2019 Disponível em: https://txm.business/. Acesso em: 16 junho 2020.

VALERO SANCHO, J. L. 2001. La Infografia: Técnicas, Análisis y Usos Periodísticos. Universidad Autónoma de Barcelona.

WURMAN, Richard Saul. Ansiedade de Informação 2: um guia para quem comunica e dá instruções. São Paulo: Editora Cultura Ltda., 2001. 328 p. Pesquisas e textos adicionais: Loring Leifer e David Sume. 


\section{Naiane Cristina Salvi}

Ph.D. Candidate, Naiane has a Master Degree in Design by Federal University of Santa Catarina. Also, is graduated in Fashion Design at University of the State of Santa Catarina, specialist in fashion design creation, and has a technological degree at Fashion Business Management. Has experiences as a researcher in the field of creative business, innovation and design, working with new business creation, dealing specially with business design for new entrepreneurs.

\section{Hecate Torres-Angenot}

Hecate is Graduated in Design from Federal University of Santa Catarina, and nowadays is the designer at TXM Methods startup. During graduation, she participated in the TXM Business research group as a first stage researcher.

\section{Paola Gallert Thomé da Cruz}

Paola is Graduated in Design from Federal University of Santa Catarina, and works as a Social Media designer. During graduation, she participated in the TXM Business research group as a first stage researcher.

\section{Luiz Salomão Ribas Gomez}

Luiz Salomão Ribas Gomez has a degree in Industrial Design from Pontifícia Universidade Católica do Paraná, a master's degree in Production Engineering from Universidade Federal de Santa Catarina and a doctorate in Production Engineering from Universidade Federal de Santa Catarina, revalidated at Universidade da Beira Interior (UBI) as Doctorate in Industrial Engineering and Management. He is currently an Associate Professor IV at the Federal University of Santa Catarina where he coordinated the Laboratory for the Orientation of Organizational Genesis LOGO and also the project Centro Sapiens. Conducted in 2009, Pos-Doc with UNIDCOM - IADE in Lisbon with the theme "Brand DNA" and also held a senior internship at Saxion University of Applied Science with the theme "Innovation, creative economy and maker spaces". Currently coordinates 
the project Cocreation Lab (TXM Business), the largest network of laboratories for pre-incubation of innovative businesses in Latin America. He is editor of e-Revista LOGO. He has experience in the areas of Design, Innovation and Creative Entrepreneurship.

\section{Francisco Antonio Pereira Fialho}

Has degrees in Electronic Engineering from Pontifícia Universidade Católica do Rio de Janeiro (1973) and Psychology from Universidade Federal de Santa Catarina (1999), Master in Production Engineering, Ergonomics, from Universidade Federal de Santa Catarina (1992) and PhD in Production Engineering, Knowledge Engineering, from Universidade Federal de Santa Catarina (1994). He is currently a full professor at the Federal University of Santa Catarina. He has experience in the field of Knowledge Engineering and Management, working mainly on the following topics: knowledge engineering, knowledge media, eco-ergonomics, knowledge management and cognitive ergonomics. Leader of the Center for Studies and Development in Knowledge and Consciousness - NEDECC. Leader of the Center for Research in Complexity and Cognition - NUCOG. Participant of the Center of Integration Engineering and Knowledge Governance for Innovation - ENGIN of the Federal University of Santa Catarina - UFSC and LGR - Laboratory of Responsible Management. 